\title{
Culture of patient safety: evaluation of nurses*
}

\author{
Cultura de segurança do paciente: avaliação de enfermeiros
}

Silvana Pagani ${ }^{1}$, Karla Crozeta ${ }^{1}$, Alexandra Berndt Razeira Crisigiovanni ${ }^{1}$

Objective: to evaluate the safety culture of the teaching hospital patient. Methods: evaluative research, with 68 nurses, whose instrument used was the Safety Attitudes Questionnaire - Short Form adapted, composed of questions covering six domains. Results: the best evaluation was of the Satisfaction at Work domain, with an average of 88.48, the only one positively classified. The domain that measures the Perception of Management of the Unit and the Hospital obtained smaller evaluations, with averages 61.1 and 59.6, respectively. Conclusion: nursing professionals expressed satisfaction with the work; however, considering that only one domain had a positive result, the safety culture of the hospital patient presents weaknesses from the perspective of the participating nurses.

Descriptors: Nursing; Patient Safety; Organizational Culture.

Objetivo: avaliar a cultura de segurança do paciente de hospital de ensino. Métodos: pesquisa avaliativa, com 68 enfermeiros, cujo instrumento utilizado foi o Questionário de Atitudes de Segurança (Safety Attitudes Questionnaire - Short Form) adaptado, composto por questões que contemplam seis domínios. Resultados: a melhor avaliação foi do domínio Satisfação no Trabalho, com média de 88,48, único classificado positivamente. 0 domínio que mede a Percepção da Gerência da Unidade e do Hospital obteve as menores avaliações, com médias 61,1 e 59,6, respectivamente. Conclusão: os profissionais enfermeiros exprimiram satisfação com o trabalho, porém, considerando que apenas um domínio obteve resultado positivo, a cultura de segurança do paciente encontrada no hospital apresenta fragilidades na perspectiva dos enfermeiros participantes.

Descritores: Enfermagem; Segurança do Paciente; Cultura Organizacional.

\footnotetext{
*Extracted from the Dissertation "Qualidade da higienização hospitalar e a segurança do paciente: avaliação e planejamento de estratégias", Universidade Federal do Paraná, 2018.

${ }^{1}$ Universidade Federal do Paraná. Curitiba, PR, Brazil. 


\section{Introduction}

Concerns about the quality of care provided in the area of health and patient safety are not recent. However, today, we have studied the subject in a more stubborn way, with the development of research to evaluate the provision of health services.

In Brazil, the ordinance from the Health Department, which instituted the National Patient Safety Program, has as a strategy for implementation the promotion of a safety culture ${ }^{(1)}$, which is defined as the set of values and behaviors that establish the commitment to health care safety, substituting and teaching the problem of learning from flaws and improving attention to health ${ }^{(2)}$.

It is worth highlighting that in health institutions, one of the requirements to avoid the occurrence of incidents is the safety culture, through risk management, in which professionals communicate errors and act proactively, redesigning processes to prevent new incidents. With the analysis of the organizational culture, it is possible to identify how the institution is, what it intends to be and what management is able to accomplish to achieve quality and develop a culture focused on patient safety ${ }^{(3)}$.

The periodic evaluation of the safety culture, using validated questionnaires, allows us to recognize the actual state of the safety culture in the institution, and also enables monitoring of this culture after improvement interventions ${ }^{(4)}$.

And, in the organizational scope, nurses have a unique position in health institutions, due to the condition of manager and direct provider of patient care. In view of this, the perceptions of health in the evaluation of the culture of patient safety in health institutions bring information relevant to the planning of actions, with a view to improving patient care and safety ${ }^{(5)}$. In this way, the research carried out with nurses aimed to evaluate the safety culture of the patient in a teaching hospital.

\section{Methods}

It is an evaluative research, developed in a teaching hospital, reference in trauma, of the State Department of Health of Paraná, in the city of Curitiba, Brazil, from October 2017 to June 2018.

The study population consisted of nurses working at the Nursing Board, distributed in the hospital sectors, totaling 79 professionals. The inclusion criterion was more than six months in the institution. Professionals who had been suspended during the period of data collection were excluded. The definition of the minimum period of six months in the institution aimed to reduce the divergences arising from the internal and external evaluation of culture by professionals, given that in organizations there may be a cultural mosaic rather than a uniform culture, considered that the cultural process consists of learning accumulated and shared by a certain group in the institution's environment $^{(6)}$. After applying these criteria, seventy nurses effectively received the instrument of data collection and the Free and Informed Consent Term. A total of 68 questionnaires were returned, with two losses occurring. It is worth noting that in order to achieve a $95.0 \%$ confidence level, a margin of error equals to $4.5 \%$, a conservative prevalence ratio of 0.5 (for any characteristic) and a finite population size (79 employees), would require a sample of 66 professionals.

Data were collected through the application of the Safety Attitudes Questionnaire (SAQ) Short Form 2006, translated and cross-culturally adapted to Brazil. The final score of the instrument varies from 0 to 100 , where zero represents the worst perception of the security Environment and 100 indicates the best perception. Following the authors' recommendations, the values are considered positive when the total score is greater than or equals to $75^{(7)}$. The score is sorted as follows: Totally Disagree (TD), equals to 0 points; Par- 
tially Disagree (PD), 25 points; Neutral (N), 50 points; Partially Agree (PA), 75 points; Totally Agree (TA), 100 points; and, lastly, Not Applicable, zero point ${ }^{(7)}$.

The quantitative data were inserted in Excel $^{\circledR}$ spreadsheet and, later, the Software R (R Core Team, 2017) was used for statistical analysis. In the counting of the scores, it is clarified that the results of the reverse questions two and 11 were recoded, so the completed responses as TA were inverted and became TD, and thus for all the responses of the reverse questions $^{(7)}$.

The SAQ variant used contains 41 questions, however, in this analysis; it was decided to use questions that configure the socio-demographic variables and the six domains of the instrument by focusing on the safety culture. The six domains consisting of 32 questions are: Teamwork Environment, Safety, Job Satisfaction, Stress Perception, Perception of the Unit and Hospital Management and Working Conditions. Thus, the grouping of the items in domains occurred by the calculation of the average (together with the results of the evaluation of the number of domains of the domain). The questions of the SAQ questionnaire which refer to collaboration between teams and communication failures, $(14,33,34,35$ and 36) defined as other questions were not used because they did not fit into the domains ${ }^{(7)}$. The absolute and relative frequency of the variables was analyzed.

The ethical aspects established by Resolution no 466/2012 of the National Health Council were respected. The project was approved by the Ethics Committees in Research of the Health Sciences Sector and by the Hospital do Trabalhador (Worker's Hospital), in accordance with opinions $\mathrm{n}-2,024,970$ and no 2,634,621 and Certificate of Presentation for Ethical Assessment no 66939717,3,0000,0102 and no $66939717,3,3002,5225$, respectively.

\section{Results}

From the analysis of the 68 questionnaires answered, there was predominance of females $(82.3 \%)$ in relation to males $(17.6 \%)$. Regarding the time in the institution, $29.4 \%$ were in the institution between 3 and 4 years, 25\% from 11 to 20 years, $23.5 \%$ from 5 to 10 years, $13.2 \%$ from 1 to 2 years, $4.4 \%$ from 6 to 11 months and 4.4\% from 21 years. About the labor bond, $51.4 \%$ were in the CLT system (Consolidated Labor Laws) and 48.5\% public servants; on the work shift, $73.5 \%$ worked in the daytime and the rest (26.4\%) at night.

Among the domains analyzed, the averages showed that the best evaluated was Satisfaction at Work, with a mean of 88.4, followed by Stress Perception (73.8), Team Work Environment (73.5), Safety (68.7), Working Conditions (62.1), Perception of Unit Management (61.1) and Hospital Management (59.6).

In Table 1, the responses of the domains of Team Work Environment and Safety were grouped. Regarding the Working Environment, 49.0\% of the respondents partially agreed that the nurses' suggestions were well received; $35.0 \%$ disagreed partially that it was difficult to speak openly when perceiving a problem with patient care (reverse question); $51.0 \%$ partially agreed that they received support from members of other teams to care for patients; $56.0 \%$ fully agreed that it was easy to ask when there was something they did not understand; and $65.0 \%$ partially agreed that doctors and nurses worked together as a well coordinated team.

The Security Environment domain shows that questions 7 (I would feel safe if I were treated here as a patient), 9 (I am aware of the appropriate means to address patient safety issues in this area) and 12 (I am encouraged by my colleagues to report any concerns I may have) have achieved Fully Agree response rates equals to or greater than $50.0 \%$. On the other hand, the culture that errors are handled properly, in question 8 , showed that $47.0 \%$ agreed partially with the affirmative, in addition to presenting $21.0 \%$, equally, to the items Partially Disagree and Totally Agree. Question 11 (In this area, it is difficult to discuss errors) presented the highest proportion of Partially Disagree answers, with 34.0\%. Questions 10 and 13, referring to the return on performance and the culture of learning from mistakes, presented higher values of Neutral responses, 16 and $15.0 \%$, respectively. 
Table 1 - Distribution of responses referring to the domains of Team Work Environment and Safety

\begin{tabular}{|c|c|c|c|c|c|c|c|}
\hline \multirow{2}{*}{ Safety Attitudes Questionnaire } & TD & PD & $\mathbf{N}$ & PA & TA & NA & MI \\
\hline & $n(\%)$ & n (\%) & n (\%) & n (\%) & n (\%) & n (\%) & n (\%) \\
\hline \multicolumn{8}{|l|}{ Teamwork environment } \\
\hline 1. Your suggestions for nurses are welcome in this area. & $1(1.0)$ & $3(4.0)$ & $4(6.0)$ & $33(49.0)$ & $27(40.0)$ & - & - \\
\hline $\begin{array}{l}\text { 2. (R) In this area, it is difficult to speak openly if I perceive a problem } \\
\text { with patient care }\end{array}$ & $6(9.0)$ & $24(35.0)$ & $4(6.0)$ & $16(24.0)$ & $18(26.0)$ & - & - \\
\hline $\begin{array}{l}\text { 3. In this area, disagreements are resolved appropriately (eg not who is } \\
\text { right, but what is best for the patient) }\end{array}$ & $4(6.0)$ & $7(10.0)$ & $8(12.0)$ & $20(29.0)$ & $29(43.0)$ & - & - \\
\hline 4. I have the support I need from other team members to care for patients & $1(1.0)$ & $5(7.0)$ & $3(4.0)$ & $35(51.0)$ & $23(34.0)$ & $1(1.0)$ & - \\
\hline $\begin{array}{l}\text { 5. It is easy for professionals working in this area to ask questions when } \\
\text { there is something they do not understand }\end{array}$ & $4(6.0)$ & $6(9.0)$ & $4(6.0)$ & $15(22.0)$ & $38(56.0)$ & $1(1.0)$ & - \\
\hline $\begin{array}{l}\text { 6. The doctors and nurses here work together as a well-coordinated } \\
\text { team. }\end{array}$ & $1(1.0)$ & $4(6.0)$ & $3(4.0)$ & $44(65.0)$ & $15(22.0)$ & $1(1.0)$ & - \\
\hline \multicolumn{8}{|l|}{ Safety } \\
\hline 7. I would feel safe if I was treated here as a patient & $1(1.0)$ & $7(10.0)$ & $3(4.0)$ & $18(26.0)$ & $37(54.0)$ & - & $2(3.0)$ \\
\hline 8. Errors are handled appropriately in this area & $4(6.0)$ & $14(21.0)$ & $3(4.0)$ & $32(47.0)$ & $14(21.0)$ & $1(1.0)$ & - \\
\hline $\begin{array}{l}\text { 9. I know the appropriate means to address patient safety issues in this } \\
\text { area. }\end{array}$ & $2(3.0)$ & $4(6.0)$ & $2(3.0)$ & $21(31.0)$ & $38(56.0)$ & $1(1.0)$ & - \\
\hline 10. I get proper feedback on my performance & $9(13.0)$ & $11(16.0)$ & $11(16.0)$ & $20(29.0)$ & $16(24.0)$ & $1(1.0)$ & - \\
\hline 11. (R) In this area, it is difficult to discuss & $9(13.0)$ & $23(34.0)$ & $7(10.0)$ & $15(22.0)$ & $13(19.0)$ & $1(1.0)$ & - \\
\hline 12. I am encouraged by my colleagues to report any concerns I may have & $4(6.0)$ & $6(9.0)$ & $7(10.0)$ & $16(24.0)$ & $34(50.0)$ & $1(1.0)$ & - \\
\hline $\begin{array}{l}\text { 13. The culture in this area makes it easy to learn from the mistakes of } \\
\text { others }\end{array}$ & $5(7.0)$ & $5(7.0)$ & $10(15.0)$ & $26(38.0)$ & $21(31.0)$ & $1(1.0)$ & - \\
\hline
\end{tabular}
TD: Totally Disagree; PD: Partially Disagree; N: Neutral; PA: Partially Agree; TA: totally agree; NA: Not applicable; MI: Missing information; R: Reverse

Table 2 presents the domains Satisfaction at Work and Stress Perception. As for the first, the percentages of those who agree fully were distributed as follows: $81.0 \%$ liked work, $66.0 \%$ had worked in the institution as part of a large family, $79.0 \%$ had agreed that it was a good place, $82.0 \%$ had a great time working in the area. In the field of Stress Impairment,
$51.0 \%$ fully agreed that performance was impaired with excessive workload, $53.0 \%$ fully agreed that they were less efficient when tired, $38.0 \%$ understood that they were more likely to commit errors in hostile situations and $31,0 \%$ fully agreed that fatigue impaired performance in emergency situations. 
Table 2 - Distribution of responses concerning the domains Satisfaction at Work and Stress Perception

\begin{tabular}{|c|c|c|c|c|c|c|c|}
\hline \multirow{2}{*}{ Safety Attitudes Questionnaire } & TD & PD & $\mathbf{N}$ & PA & TA & NA & $\mathbf{v}$ \\
\hline & n (\%) & n (\%) & n (\%) & n (\%) & n (\%) & n (\%) & n (\%) \\
\hline \multicolumn{8}{|l|}{ Job satisfaction } \\
\hline 15. I like my job & $0(0)$ & $0(0)$ & $4(6.0)$ & $7(10.0)$ & $55(81.0)$ & $2(3.0)$ & - \\
\hline 16. Working here is like being part of a big family. & $2(3.0)$ & $1(1.0)$ & $5(7.0)$ & $12(18.0)$ & $45(66.0)$ & $2(3.0)$ & $1(1.0)$ \\
\hline 17. This is a good place to work & - & $2(3.0)$ & $3(4.0)$ & $7(10.0)$ & $54(79.0)$ & $2(3.0)$ & - \\
\hline 18. I am proud to work in this area. & - & $2(3.0)$ & $2(3.0)$ & $6(9.0)$ & $56(82.0)$ & $2(3.0)$ & - \\
\hline 19. Morale in this area is high & $2(3.0)$ & $6(9.0)$ & $10(15.0)$ & $25(37.0)$ & $24(35.0)$ & $1(1.0)$ & - \\
\hline \multicolumn{8}{|l|}{ Perception of stress } \\
\hline 20. When my workload is excessive, my performance is impaired & $3(4.0)$ & $1(1.0)$ & $4(6.0)$ & $25(37.0)$ & $35(51.0)$ & $0(0)$ & - \\
\hline 21. I am less efficient at work when I'm tired & $2(3.0)$ & $7(10.0)$ & $2(3.0)$ & $18(26.0)$ & $36(53.0)$ & $3(4.0)$ & - \\
\hline 22. I am more likely to make mistakes in tense or hostile situations & $7(10.0)$ & $8(12.0)$ & $2(3.0)$ & $23(34.0)$ & $26(38.0)$ & $2(3.0)$ & - \\
\hline $\begin{array}{l}\text { 23. Tiredness impairs my performance during emergencies (eg.: } \\
\text { cardiorespiratory resuscitation, seizures) }\end{array}$ & $11(16.0)$ & $12(18.0)$ & $4(6.0)$ & $17(25.0)$ & $21(31.0)$ & $3(4.0)$ & - \\
\hline
\end{tabular}

DT: Totally Disagree;PA: Partially Disagree; N: Neutral; PA: Partially Agree; TA: Totally Agree; NA: Not applicable; V: Void

Table 3 shows the Perception of Unit and Hospital Management and Working Conditions domains. It is observed in questions 24 to 28, on both Managements, the presence of the answers Not Applicable and, especially, Missing Information, being that in other domains these results were so frequent.

It is pointed out that $37.0 \%$ fully agreed that they received support from Unit Management in their daily efforts (question 24), and $24.0 \%$ admitted receiving this support from Hospital Management. It is emphasized that $18.0 \%$ fully agreed that the administration of both the Unit and the Hospital did not compromise patient safety (question 25). As for manage- ment doing good work, question 26 , the results werehigher for the Totally Agree item and, also, with very close values, with $44.0 \%$, agreeing to the Management of the Unit; and $41.0 \%$, to that of the Hospital.

Lastly, the Working Conditions domain pointed mainly to question 31 that $40.0 \%$ of the participants fully agreed that the information needed for diagnostic decisions was routinely available. As for the hospital doing good training for new members (question 30) and adequate supervision of trainees (question 32), there were not very expressive results, since $35.0 \%$ and $29.0 \%$, respectively, partially agreed with the assertions (Table 3). 
Table 3 - Distribution of the answers referring to the domains Perception of the Management of the Unit and the Hospital and Working Conditions

\begin{tabular}{|c|c|c|c|c|c|c|c|}
\hline \multirow{2}{*}{ Safety Attitudes Questionnaire } & TD & PD & $\mathbf{N}$ & PA & TA & NA & MI \\
\hline & n (\%) & n (\%) & n (\%) & n (\%) & n (\%) & n (\%) & n (\%) \\
\hline \multicolumn{8}{|l|}{ Perception of unit and hospital management } \\
\hline 24. Management supports my daily efforts: (Unit) & $4(6.0)$ & $2(3.0)$ & $7(10.0)$ & $18(26.0)$ & $25(37.0)$ & $1(1.0)$ & $11(16.0)$ \\
\hline 24. Management supports my daily efforts: (Hospital) & $7(10.0)$ & $7(10.0)$ & $14(21.0)$ & $19(28.0)$ & $16(24.0)$ & $1(1.0)$ & $4(6.0)$ \\
\hline $\begin{array}{l}\text { 25. Administration does not consciously compromise patient safety: } \\
\text { (Unit) }\end{array}$ & $19(28.0)$ & $5(7.0)$ & $5(7.0)$ & $15(22.0)$ & $12(18.0)$ & $3(4.0)$ & $9(13.0)$ \\
\hline $\begin{array}{l}\text { 25. Administration does not consciously compromise patient safety: } \\
\text { (Hospital) }\end{array}$ & $21(31.0)$ & $4(6.0)$ & $11(16.0)$ & $13(19.0)$ & $12(18.0)$ & $2(3.0)$ & $5(7.0)$ \\
\hline 26. The administration is doing a good job: (Unit) & $1(1.0)$ & $1(1.0)$ & $7(10.0)$ & $18(26.0)$ & $30(44.0)$ & $1(1.0)$ & $10(15.0)$ \\
\hline 26. The administration is doing a good job: (Hospital) & $1(1.0)$ & $3(4.0)$ & $8(12.0)$ & $21(31.0)$ & $28(41.0)$ & $1(1.0)$ & $6(9.0)$ \\
\hline $\begin{array}{l}\text { 27. Problematic professionals of the team are treated constructively by } \\
\text { ours: (Unit) }\end{array}$ & $7(10.0)$ & $7(10.0)$ & $11(16.0)$ & $18(26.0)$ & $16(24.0)$ & $1(1.0)$ & $8(12.0)$ \\
\hline $\begin{array}{l}\text { 27. Problematic professionals of the team are treated constructively by } \\
\text { ours: (Hospital) }\end{array}$ & $8(12.0)$ & $16(24.0)$ & $13(19.0)$ & $14(21.0)$ & $13(19.0)$ & $1(1.0)$ & $3(4.0)$ \\
\hline $\begin{array}{l}\text { 28. I receive adequate and timely information about events that may } \\
\text { affect my work: (Unit) }\end{array}$ & $4(6.0)$ & $8(12.0)$ & $6(9.0)$ & $13(19.0)$ & $27(40.0)$ & $2(3.0)$ & $8(12.0)$ \\
\hline $\begin{array}{l}\text { 28. I receive adequate and timely information about events that may } \\
\text { affect my work: (Hospital) }\end{array}$ & $4(6.0)$ & $10(15.0)$ & $12(18)$ & $18(26.0)$ & $19(28.0)$ & $2(3.0)$ & $3(4.0)$ \\
\hline $\begin{array}{l}\text { 29. In this area, the number and qualification of professionals are suf- } \\
\text { ficient }\end{array}$ & $13(19.0)$ & $17(25.0)$ & $2(3.0)$ & $26(38.0)$ & $10(15.0)$ & - & - \\
\hline \multicolumn{8}{|l|}{ Work conditions } \\
\hline 30. This hospital does a good job in training new members & $11(16.0)$ & $14(21.0)$ & $8(12.0)$ & $24(35.0)$ & $11(16.0)$ & - & 11(16.0) \\
\hline $\begin{array}{l}\text { 31. All necessary information for diagnostic and therapeutic decisions } \\
\text { is routinely available to me }\end{array}$ & $4(6.0)$ & $8(12.0)$ & $6(9.0)$ & $21(31.0)$ & $27(40.0)$ & $2(3.0)$ & - \\
\hline 32. Trainees in my profession are adequately supervised & $6(9.0)$ & $13(19.0)$ & $7(10.0)$ & $20(29.0)$ & $17(25.0)$ & $5(7.0)$ & - \\
\hline
\end{tabular}

\section{Discussion}

As a limitation of the study, we highlight the application of the research only to a group of professionals of the institution, the nurses. Subsequent studies can be applied to the multi professional team to provide a more comprehensive portrayal of the patient's safety culture in the institution.

The superior result of female professionals is in line with other studies ${ }^{(8-9)}$ and corroborates with data from the Federal Nursing Council, in which the number of women represented $86.2 \%$ of the nurses ${ }^{(10)}$.
The application of the SAQ allows knowing the perceptions of the participants in relation to the safety culture in several domains and the scores that are $\geq 75$ are considered positive values, expressing strengthened areas in relation to the culture ${ }^{(11)}$.

The analysis of the Teamwork Environment, related to the understanding of the quality of the relationship between the multi professional teams, reached an average of 73.5, which corroborates with studies carried out in Brazil, whose average values were $68.3^{(12)}, 75^{(11)}$ and $70.1^{(8)}$. 
The findings for this domain are close to the positive result, which is important, since the work in the health services is developed by a multi professional team that must be clarified regarding the roles of each professional category and the responsibilities with the patient's safety, resolving conflicts and sharing information ${ }^{(13)}$.

The Safety Environment (average 68.7), whose result is similar to the average 68.8 of another resear$\mathrm{ch}^{(11)}$, is associated with the professional's perception of the error and how it is conducted in the institution, it concerns the encouragement of professionals in reporting patient safety concerns and the opportunity to learn from others' mistakes ${ }^{(14)}$. This domain, although it did not reach positive value, came close, which means the relevant information about the understanding of the safety situation in the hospital.

The domain Satisfaction at Work, average 88.4, was the only one with positive evaluation. Studies that applied SAQ found positive, but lower values than in this study, such as $80.5^{(12)}$ and $81.2^{(11)}$, these results of studies performed in public hospitals; and 78.3, in a philanthropic hospital ${ }^{(8)}$. This result is significant, since professional satisfaction can influence the reduction of adverse events ${ }^{(15)}$, as well as boost the professional's development and productivity ${ }^{(13)}$.

The result of the Stress Perception was close to the positive score (73.8), which may indicate that the participants recognized when stressful conditions influence the execution of activities. Studies relate the health professional's illness processes to stressful factors or circumstances, which can lead to unsafe care $^{(13)}$.

Perception related to Hospital and Unit Management presented the evaluations with lower results, which shows the fragility of the safety culture at the administrative level. This negative perception may indicate that caregivers do not recognize the concern of managers with the latent factors of the safety culture, denoting the need for interventions ${ }^{(16)}$. Meanwhile, if, on the one hand, the weighting was negative, on the other, it allows the opportunity for improvement to managerial issues related to the safety culture.

In Working Conditions, it can be inferred from the answers that there is a deficiency in the capacities and in the process of continuing education within the institution, as well as lack of access to the information related to the patient.

The importance of lifelong education is undoubtedly important in order to strengthen safe practices, since the better trained health professional produces safer care, preventing the occurrence of errors and adverse events ${ }^{(17)}$. Regarding the scarcity of information, it is pointed out that, when the professional does not have them, it is limited to the practice of care, which leads to loss of autonomy and increased risk of incidents with potential to cause harm to the patient ${ }^{(13)}$.

The results of the last two domains, which presented the lowest averages, have similarities with national studies ${ }^{(12,18)}$, which even had lower averages, such as $39.0^{(18)}$ and $52.4^{(12)}$ for Management Perception; and $40.0^{(18)}$ and $53.5^{(12)}$ for Working Conditions. Therefore, there are two aspects related to patient safety that must be worked in health institutions and especially in the place studied.

\section{Conclusion}

The research demonstrated that the patient's safety culture was in the research institution. Of the domains explored, the best evaluated was Satisfaction at work, also, the only one that obtained a positive result, above 75 , which shows a positive effect for this item. The domain that refers to the perception of the management of the place, acquired less evaluation, reflecting the thinking of the participating nurses of not recognizing the manager as involved in the safety of the patient. 


\section{Collaborations}

Pagani S, Crozeta K and Crisigiovanni ABR contributed in the design, analysis and interpretation of the data, article writing, critical review of the relevant intellectual content and final approval of the version to be published.

\section{References}

1. Ministério da Saúde (BR). Portaria no 529, de 1o de abril de 2013: institui o Programa Nacional de Segurança do Paciente (PNSP). Brasília: Ministério da Saúde; 2013.

2. Ministério da Saúde (BR). Resolução da Diretoria Colegiada no 36, de 25 de julho de 2017: institui ações para a segurança do paciente em serviços de saúde e dá outras providências. Brasília: Ministério da Saúde; 2017.

3. Tobias GC, Bezerra ALQ, Branquinho NCS, Silva AEBC. Cultura de segurança do paciente em instituições de saúde: um estudo bibliométrico. Enferm Glob [Internet]. 2014 [citado 2019 fev. 19]; 13(1):336-61. Disponível em: http://scielo. isciii.es/pdf/eg/v13n33/pt_revision1.pdf

4. Carvalho REFL, Arruda LP, Nascimento NKP, Sampaio RL, Cavalcante MLSN, Costa ACP. Assessment of the culture of safety in public hospitals in Brazil. Rev Latino-Am Enfermagem. 2017; 25:e2849 doi: dx.doi.org/10.1590/15188345.1600 .2849

5. Costa DB, Ramos D, Gabriel CS, Bernardes A. Patient safety culture: evaluation by nursing professionals. Texto Contexto Enferm. 2018; 27(3):e2670016. doi: dx.doi.org/10.1590/0104070720180002670016

6. Fonseca PH, Lowen IMV, Lourenço ML, Peres AM. Cultura organizacional na área da saúde: um estudo bibliométrico. Saúde Debate. 2018; 42(116):318-30. doi: dx.doi.org/10.1590/01031104201811626
7. Carvalho REFL, Cassiani SHB. Cross-cultural adaptation of the Safety Attitudes Questionnaire - Short Form 2006 for Brazil. Rev Latino-Am Enfermagem. 2012; 20(3):575-82. doi: http:// dx.doi.org/10.1590/S0104-11692012000300020

8. Matiello RDC, Lima EFA, Coelho MCR, Oliveira ERA, Leite FMC, Primo CC. Patient safety culture from the perspective of nurses. Cogitare Enferm. 2016; 21(esp):1-9. doi: http://dx.doi.org/10.5380/ ce.v21i5.45408

9. Misiak M, Radünz V, Dal Sasso GTM, Tourinho FSV. Atitudes para cultura de segurança do paciente em uma instituição cardiovascular. Rev Varia Sci [Internet]. 2016 [citado 2019 Fev. 19]; 2(2):10214. Disponível em: http://saber.unioeste.br/index. php/variasaude/article/view/15453/10777

10. Conselho Federal de Enfermagem (BR). Pesquisa perfil da enfermagem no Brasil [Internet]. 2013 [citado 2019 fev. 19]. Disponível em: http://www. cofen.gov.br/perfilenfermagem/blocoBr/Blocos/ Bloco1/bl_ident-socio-economica-enfermeiros. pdf

11. Santiago THR, Turrini RNT. Organizational culture and climate for patient safety in Intensive Care Units. Rev Esc Enferm USP. 2015; 49(esp):123-30. doi: dx.doi.org/10.1590/S0080623420150000700018

12. Luiz RB, Simões ALA, Barichello E, Barbosa MH. Factors associated with the patient safety climate at a teaching hospital. Rev Latino-Am Enfermagem. 2015; 23(5):880-7. doi: dx.doi. org/10.1590/0104-1169.0059.2627

13. Fermo VC, Radünz V, Rosa LM, Marinho MM. Professional attitudes toward patient safety culture in a bone marrow transplant unit. Rev Gaúcha Enferm. 2016; 37(1):e55716. doi: dx.doi. org/10.1590/1983-1447.2016.01.55716

14. Smits M, Keizer E, Giesen P, Deilkås ECT, Hofoss D, Bondevik GT. Patient safety culture in out-ofhours primary care services in the Netherlands: a cross-sectional survey. Scand J Prim Health Care. 2018; 36(1):28-35. doi: https://doi.org/10.1080/ 02813432.2018 .1426150 
15. Padilha KG, Barbosa RL, Andolhe R, Oliveira EM, Ducci AJ, Bregalda RS, et al. Nursing workload, stress/burnout, satisfaction and incidents in a trauma intensive care units. Texto Contexto Enferm. 2017; 26(3):e1720016. doi: http:// dx.doi.org/10.1590/0104-07072017001720016

16. Carvalho PA, Göttems LBD, Pires MRGM, Oliveira MLC. Safety culture in the operating room of a public hospital in the perception of healthcare professionals. Rev Latino-Am Enfermagem. 2015; 23(6):1041-8. doi: dx.doi.org/10.1590/01041169.0669 .2647
17. Tavares APM, Moura ECC, Avelino FVSD, Lopes VCA, Nogueira LT. Patient safety culture from the perspective of the nursing team. Rev Rene. 2018; 19:e3152. doi: http://dx.doi.org/10.15253/21756783.2018193152

18. Marinho MM, Radünz V, Barbosa SFF. Assessment of safety culture by surgical unit nursing teams. Texto Contexto Enferm. 2014; 23(3):581-90. doi: dx.doi.org/10.1590/0104-07072014002640012 